\title{
To Dine, or Not to Dine on a Cruise Ship in the Time of the COVID-19 Pandemic: The Tripartite Approach towards an Understanding of Behavioral Intentions among Female Passengers
}

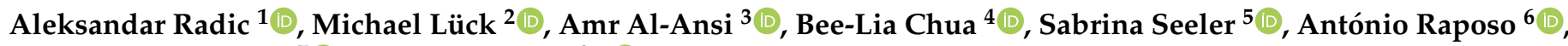 \\ Jinkyung Jenny Kim ${ }^{7}$ (D) and Heesup Han ${ }^{3, *(D)}$ \\ check for \\ updates \\ Citation: Radic, A.; Lück, M.; \\ 1 Independent Researcher, Gornji kono 8, 20000 Dubrovnik, Croatia; aleradic@gmail.com \\ 2 School of Hospitality \& Tourism, Auckland University of Technology, Private Bag 92006, \\ Auckland 1142, New Zealand; michael.lueck@aut.ac.nz \\ 3 College of Hospitality and Tourism Management, Sejong University, Seoul 05006, Korea; \\ amralansi1@gmail.com \\ 4 Department of Food Service and Management, Universiti Putra Malaysia, \\ Seri Kembangan 43400, Selangor, Malaysia; chuabeelia@upm.edu.my \\ 5 DITF-German Institute for Tourism Research, West Coast University of Applied Sciences, \\ 25746 Heide, Germany; seeler@fh-westkueste.de \\ 6 CBIOS (Research Center for Biosciences and Health Technologies), Universidade Lusófona de Humanidades \\ e Tecnologias, Campo Grande 376, 1749-024 Lisboa, Portugal; antonio.raposo@ulusofona.pt \\ 7 School of Hotel and Tourism Management, Youngsan University, Busan 48015, Korea; \\ jennykim1120@gmail.com \\ * Correspondence: heesup.han@gmail.com
} Al-Ansi, A.; Chua, B.-L.; Seeler, S.; Raposo, A.; Kim, J.J.; Han, H. To Dine, or Not to Dine on a Cruise Ship in the Time of the COVID-19 Pandemic: The Tripartite Approach towards an Understanding of Behavioral Intentions among Female Passengers. Sustainability 2021, 13, 2516. https://doi.org/10.3390/su13052516

Academic Editor: Kisang Ryu

Received: 28 January 2021

Accepted: 20 February 2021

Published: 26 February 2021

Publisher's Note: MDPI stays neutral with regard to jurisdictional claims in published maps and institutional affiliations.

Copyright: (c) 2021 by the authors. Licensee MDPI, Basel, Switzerland. This article is an open access article distributed under the terms and conditions of the Creative Commons Attribution (CC BY) license (https:// creativecommons.org/licenses/by/ $4.0 /)$.
Abstract: Given that cruise line companies are rushing to restart their operations with modified dining services, the aim of this research is to establish a conceptual framework that precisely outlines female passengers' behavioral intentions towards dining on cruise ships in the time of the COVID-19 crisis. It does so by extending the theory of reasoned action (TRA) by including the social servicescape of the cruise ship dining experiencescape (stimulus-organism-response (S-O-R) paradigm) and perceived health risk from COVID-19 (the prospect theory). The developed theoretical framework based on this tripartite approach has predictive power for intentions. Its effectiveness and comprehensiveness are also demonstrated. Despite the positive effect of the social servicescape on attitude and emotions and the positive attitude of female cruise travelers, the negative effect of the perceived health risk from COVID-19 appears to be the dominant factor that ultimately discourages the behavioral intentions of female cruise passengers towards dining on a cruise ship in the time of the COVID-19 pandemic. The present research provides a crucial guiding framework that helps cruise academics and operators to maximize existing and potential passengers' favorable decisions and behaviors for cruise ship dining.

Keywords: dining experiencescape; cruises; female passengers; COVID-19; risk perception; S-O-R paradigm; theory of reasoned action; prospect theory

\section{Introduction}

Cruise tourism has often been celebrated as the fastest-growing segment within the global tourism industry [1]; however, the COVID-19 outbreak in early 2020 forever changed the landscape of the cruise industry. The Cruise Lines International Association (CLIA) predicted that 32 million passengers would take a cruise in 2020 [2], yet, due to the COVID19 pandemic, not even 600,000 passengers completed their cruises in 2020 [3]. Furthermore, from a worldwide fleet of 315 ocean-going cruise ships [4], on 1 January 2021, only 23 were in service [5]. As government lockdowns and global travel restrictions have halted the ocean cruise industry [6], major cruise line companies have been left without any 
revenue; thus, Carnival Corporation is losing USD 530,000,000 per month, Royal Caribbean Group is losing USD 270,000,000 per month and Norwegian Cruise Line Holdings is losing USD 175,000,000 per month [7]. It is safe to say that these major cruise line companies are experiencing an existential crisis of epic proportions [8]. As a result, Sharma and Nicolau [9] reported uneasiness about the influence of the COVID-19 incident on future prospects of the cruise industry, mainly due to its hedonic nature and the cruise industry business-leisure traveler ratio which is the lowest compared to the hotel, airline and car rental sectors [9]. It is predicted that cruise line companies will not be profitable until 2022, and it will take at least 10 years for the cruise industry to recover to the levels prior to the pandemic [10].

At the end of October 2020, the U.S. Centers for Disease Control and Prevention (CDC) announced the Framework for Conditional Sailing Order for a phased-in approach and return to service for the cruise industry in the United States [11] which supersedes a No Sail Order issued on 14 March 2020 [12]. Among many other things, the Framework requires cruise line companies to discontinue self-service buffets, to modify dining services and to manage physical distancing on board their vessels.

It is argued that the dining experience is one of the essential constructs of the overall cruise experience [13-16]. Bennett [13] described the cruise ship dining experience as a borderless multisensory environment where diners are simultaneously everywhere and nowhere. Lallani $[13,14]$ described "metaphorical travel" where guests transcend themselves to other cultural identities through food consumption on board cruise ships in ethnic and themed restaurants. As a highly emotional, memorable event [17], the cruise experience is cocreated by the multisensory servicescape and interactive social servicescape [1] and involves a number of servicescape constructs that include atmospherics, social interactions and, importantly here, dining services [16].

In today's world, women are extending their independences into every aspect of their life including travel and dining [18]. Traveling provides enjoyment to female travelers through the escape from daily routines, social bonding and hedonic pleasure [19]. Moreover, Chrusciel [20] argued that female bachelor travelers are attracted to cruises under the influence of romanticized images such as candlelit dinners and colorful sunsets. In line with this trend, and due to the increased number of female passengers [21], the Cruise Lines International Association outlines a strong demand regarding female-centered itineraries [21]. When it comes to the consumption of tourism products and services, strong evidence shows that there are clear differences between men and women [22]. Thus, it does not come as a surprise that gender is considered a robust factor that shapes consumers' behavior [23]. In studies of consumer behavior, women are reported to have weaker attitudes and subjective norms regarding certain products and services than men [24]. In the midst of the coronavirus crisis, a recent study by Karl et al. [25] showed that middle-aged female travelers are willing to consider traveling to destinations affected by health risks.

As major cruise lines are gearing towards the restart of their operations, trial cruises with modified dining services and carefully managed physical distancing as a part of the CDC's Conditional Sailing Order [26], the intention of this paper is to offer an in-depth theoretical understanding of female passengers' behavioral intentions. Female passengers have a robust tendency to take protective measures against the COVID-19 infection [27] and they represent the dominant gender among cruise travelers [21]. More precisely, the pioneering study described here sets out to investigate female passengers' behavioral intentions towards dining on cruise ships in the time of the COVID-19 pandemic, using a tripartite approach. The tripartite approach in this study relates to the theory of reasoned action (TRA) [28] extended to include Mehrabian and Russell's [29] stimulus-organismresponse (S-O-R) paradigm, and Kahneman and Tversky' s [30] prospect theory. The detailed objectives of the present research are as follows: (1) to develop a comprehensive model that offers an in-depth theoretical understanding of female passengers' behavioral intentions by adding the social servicescape of the cruise ship dining experiencescape and perceived health risk from COVID-19 to the TRA framework; (2) to identify the effect of the perceived risk to health due to the coronavirus on cruise ship dining intentions; 
and (3) to uncover the mediating role of emotional responses towards cruise ship dining intentions. To achieve the objectives of this study, the authors employed a deductive approach accompanied by a cross-sectional time horizon and quantitative techniques for data collection.

The theoretical value and originality of the present research lie in revealing the peculiar relationships within the behavioral intentions of female passengers towards dining on board cruise ships during the COVID-19 pandemic. Practically, this study can assist the struggling cruise industry by clarifying the behavioral intentions of female passengers which will allow cruise line companies to plan future steps in resuming their cruises. The results of this study show that the perceived health risk from COVID-19 has a strong negative influence that discourages female passengers' behavioral intentions to dine on cruise ships in the time of the COVID-19 pandemic. Furthermore, as cruises are all about positive emotions, the COVID-19 pandemic changed that and appears to have created a new emotional experience in the form of fear that prevents female passengers from experiencing positive emotions and exhibiting favorable behavioral intentions towards dining on board cruise ships in the time of the COVID-19 pandemic.

\section{Literature Review}

\subsection{Dining Experiencescape}

Experiencescape is a novel concept founded on the interdisciplinary approach where cultural, functional, natural, sensory and social stimuli in a service encounter are embedded in a characteristic of hospitality [31]. In this particular study, Mehrabian and Russell's [29] S-O-R paradigm was used as the foundation for the cruise ship dining experiencescape. More precisely, the authors put forward the proposition that the social servicescape of the cruise ship dining room poses particular features that can create stimuli (S) which have an effect on organisms (in this case, female passengers) $(\mathrm{O})$ and that intrinsically shape the female passengers' approach or avoidance response (R) behaviors to the cruise ship dining room. Hence, a pleasant cruise ship dining experiencescape can guide passengers towards behavior intentions such as: booking a cruise as a type of leisure activity, visiting the cruise ship dining room and/or themed restaurant, recommending a cruise to friends and family as a type of leisure activity and promoting the cruise ship dining room and/or themed restaurant. Bearing in mind that COVID-19 is transmitted person-to-person [32], Mehrabian and Russell's [29] S-O-R paradigm is useful in depicting the nature of the cruise ship social servicescape (e.g., socialization between guests and service employees, and between guests among themselves) and its effect on female cruise travelers' emotional responses that steer passengers towards approach or avoidance responses to the cruise ship dining environments. The soundness of the concept of the dining experiencescape is strengthened by contemporary empirical studies on dining experiences [33], cruise experiences [34] and cuisine creativity [35].

\subsection{The Theory of Reasoned Action (TRA)}

The reasoned action approach introduced by Martin Fishbein has evolved from the expectancy-value model (founded on the theory of attitude) to the TRA which is, today, one of the widely accepted conceptual frameworks for describing, anticipating and influencing human social behavior under complete volitional control [36]. The essence of TRA lies in two determinants of individuals' behavioral intentions, of which the first is attitude toward the behavior and the second is subjective norm toward the behavior [28]. Attitudes can be general toward certain entities and objects or specific toward distinct behaviors [37]. Subjective norms are based on the combined normative beliefs with respect to the individuals' significant other or designated social group [36]. In a nutshell, the TRA concludes that the majority of human behaviors of interest are under volitional control, where once an intention is shaped under the direct influence of attitudes and subjective norms, with great certainty, it can be anticipated that based on suitable conditions, the behavior of interest will be initiated. The strength of predicting behavioral intentions with the application 
of TRA has been confirmed by recent studies of the intention to book an Airbnb [38], the adoption of pro-tourism behaviors [39], satisfaction and positive emotions [40] and destination choices [41].

\subsection{The Prospect Theory}

The value of the prospect theory in the decision-making process based on expected utility is grounded on the basis that it can offer an alternative to classical economic theory [42]. The prospect theory relies on the premise that individuals value losses and gains differently; hence, when a person is in an uncertain situation where the probability of different outcomes is largely unknown and risk perception is relatively high, her/his final decision between probabilistic alternatives is based on perceived gains [30]. However, losses appear to be quite substantial compared to the rewards [43], and since losses carry about twice the load of the rewards, individuals are loss-averse when they choose between prospects [42]. Furthermore, the prospect theory is a useful tool in determining behavioral intentions, as it emphasizes the psychological determinants of risk perception [44]. Accordingly, the aforementioned authors claim that risk aversion for gains has concavity of the value function, and risk seeking for losses has convexity. The strength of the prospect theory is that it relates to actual choices rather than the most favorable decisions [45]. The dominance of the prospect theory in describing behavioral intentions under risk and uncertainty is well supported by recent studies on the risk evaluation of halal products/services in tourism [46], travelers' ride-sharing choices [47] and the medical tourism destination selection process [48].

\subsection{Hypotheses}

\subsubsection{The Social Servicescape, Emotions and Behavioral Intentions}

The social servicescape is a specific consumption environment that affects consumer behavior through the interaction between different social entities (e.g., service employees and customers, and between customers themselves) [49]. As guests spend prolonged time in cruise ship dining rooms, they affect each other's attitudes, and they experience several emotional responses throughout the constant interaction with service employees and other guests. Meng and Choi [50] argued that social interactions in themed restaurants exert a robust influence on customers' attitudes and their behavioral intentions. Similarly, Meng and Cui [51], in their model of extended theory of planned behavior (TPB), confirmed the significant positive impact of the experiencescape (with social servicescape aspects) on tourists' attitude in the case of home-based accommodation. The interactions between customers and service employees and between customers themselves can determine the outcome of guest experience from an emotional perspective [52].

Furthermore, dynamic consumer interaction as a part of hospitality industry experiential innovativeness can lead to favorable outcomes such as positive emotional responses and long-term relationships [53]. Proactive customer service performance is a corner stone of exceptional service, where employees at the front line are constantly aware of customers' needs to the point before the needs are needed [54]. Thus, the positive emotional response from dining can lead to a memorable experience, which has a long-lasting impact as it influences consumers' future decisions and behavioral intentions [55].

Based on our review of the academic literature and relevant empirical evidence, we propose the following hypotheses:

Hypothesis 1. The social servicescape of cruise ship dining rooms has a positive impact on female passengers' attitudes.

Hypothesis 2. The social servicescape of cruise ship dining rooms has a positive impact on female passengers' emotional responses.

Hypothesis 3. Female passengers' emotional responses have a positive impact on behavioral intentions. 


\subsubsection{Attitude, Subjective Norms and Behavioral Intentions}

Attitude is conceived as a cognitive assessment toward behavior, influenced by the voluntary beliefs about its success and denominated behavioral beliefs, in regard to the subjective estimations of final outcomes [56]. Human beings hold on to the normative beliefs of several significant people and/or designated social groups who are affecting their subjective norms. The aforementioned significant people are most often a person's partner or life companion; immediate family members and dear friends; and, based on the behavior in question, they can be even work-related associates, government officials and a general practitioner [36]. Zenker and Kock [57] argued that the COVID-19 incident holds the potential to reshape tourist attitudes and subjective norms, ultimately affecting their behavioral intentions.

Previous studies have investigated the influence of tourists' attitudes and subjective norms, while other research has focused on these determinants in the era of COVID-19. Attitude and subjective norms were also significant determinants of behavioral intentions to visit Korean green restaurants [58]. Consumers' intention to experience restaurants specializing in an organic menu was strongly influenced by attitude and subjective norms [59]. Furthermore, attitude was depicted as an essential determinant of individuals' behaviors towards making dining decisions based on online restaurant reviews [60]. In a recent systematic review and meta-analysis of 1550 studies related to predicting behavioral intention towards food safety, the authors concluded that subjective norms were the most influential variable, especially in studies with a large sample [61]. Accordingly, in the midst of the COVID-19 crisis, a recent study by Han et al. [62] demonstrated that U.S. travelers' post-pandemic travel decision-making process for safer destinations is heavily influenced by attitudes and subjective norms. Similarly, a positive attitude toward traveling has a strong potential to increase intentions to travel, while subjective norms have a limited positive impact on intentions to travel during the COVID-19 pandemic [63]. Consequently, the authors put forward the following hypotheses:

Hypothesis 4. Attitudes have a positive impact on female passengers' behavioral intentions.

Hypothesis 5. Subjective norms have a positive impact on female passengers' behavioral intentions.

\subsubsection{Perceived Health Risk of COVID-19 and Behavioral Intentions}

Perceived risk to health is described as the impending reaction of tourists' or hospitality customers' when they feel that their physical health is threatened by an uncontrolled event such as a pandemic [64]. During the COVID-19 pandemic as people are considering booking a cruise as their preferable choice of leisure, perceived health risk plays a significant role as it a demonstrates clear, robust negative effect on behavioral intentions [8]. It is known that repeat cruisers perceive health risks seriously as they consult their healthcare professionals before taking a voyage, whereas first-time cruisers follow their intuition as they take only certain precautions to avoid illness and diseases [65]. Even though repeat cruisers generally exhibit a high degree of trust towards cruise line companies, as they perceive cruises as a safe holiday [66], the negative influence of the perceived health risk of COVID-19 on behavioral intentions is gaining its momentum, particularly with the recent COVID-19 incident on the cruise ship SeaDream [67,68]. On 21 November 2020, despite the Framework for Conditional Sailing Order for a phased-in approach and return to service, the Centers for Disease Control and Prevention [69] issued a level 4 warning with the recommendation that all people should avoid travel on cruise ships because of the very high risk of COVID-19. The latest Dataessential report [70] shows that $64 \%$ of U.S. residents were likely to stay at home and minimize the risk of getting sick with the flu season approaching, 68\% would gather with fewer people for the December 2020 holidays, only $17 \%$ would have a holiday meal at a restaurant and $54 \%$ had reduced their dining at inside seating restaurants (with social distancing measures) compared to summer 2020. Research has also found that the perceived health risk from COVID-19 is consistently 
stronger in females compared to men with a robust tendency for females to take protective measures against the COVID-19 infection [27]. This review of relevant research and data led to the following hypothesis:

Hypothesis 6. The perceived health risk from COVID-19 has a negative impact on female passengers' behavioral intentions.

In summary, the authors propose a tripartite approach research framework that integrates fundamental variables of TRA (attitude and subjective norms) with the S-O-R paradigm constructs (social servicescape and emotions) and the prospect theory variable (perceived health risk from COVID-19). Our conceptual model of these relationships is presented in Figure 1.

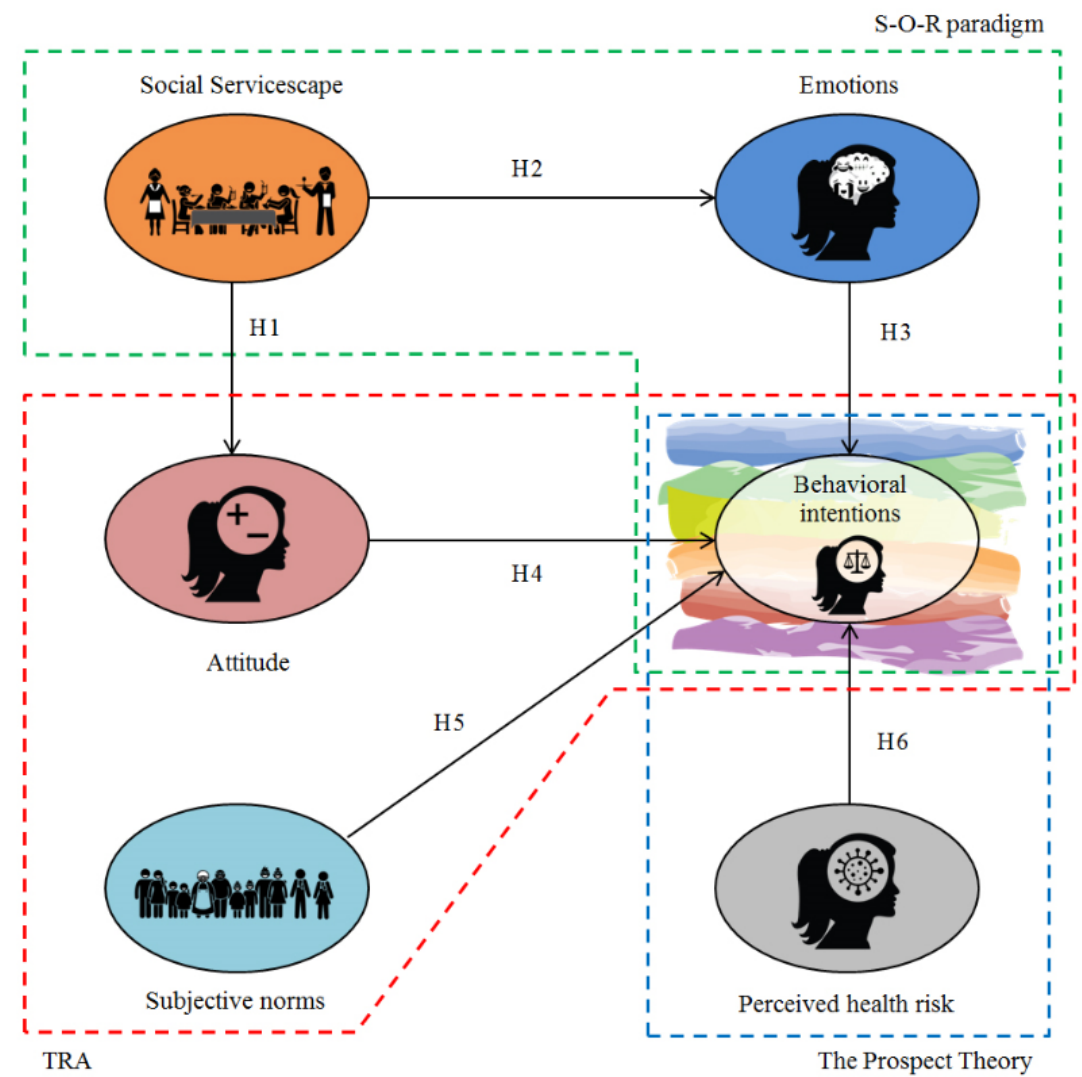

Figure 1. The conceptual model based on the tripartite approach.

\section{Method}

\subsection{Sample and Data Collection Procedure}

Female guests were deliberately chosen for this study because of their robust tendency to take protective measures against the COVID-19 infection [27], their importance to cruise line companies as they represent the dominant gender among cruise travelers [21] and due to their elevated propensity for health risk perception [25]. Furthermore, the social community of our special interest was clustered around experienced female passengers who had dined multiple times at cruise ship dining rooms and themed/ethnic restaurants in the previous 18 months. To thoroughly explore the female passengers' behavioral intentions towards dining on cruise ships in the time of the COVID-19 crisis, data were collected via self-administrated online survey cloud-based software (SurveyMonkey ${ }^{\circledR}$ ) over a sevenweek period between September and October 2020. A purposive sampling technique was applied in this study because, as Teeroovengadum and Nunkoo [71] argued, such a technique provides well-chosen participants established according to chosen criteria. Possible female adults were invited to participate in the survey through various social 
media groups (please see Table 1). The authors directly reached out to members of the social community and the sample frame contained 2507 female guests. One of the authors distributed the survey to participants and only 390 responses were returned. This represents a $15.55 \%$ response rate.

Table 1. List of social media groups from where participants were recruited.

\begin{tabular}{cr}
\hline Carnival Cruise Dining & https://www.facebook.com/groups/566712757126641 \\
\hline Princess Cruises_Passenger Forum & https://www.facebook.com/groups/771427119576844 \\
\hline Celebrity Cruises & https://www.facebook.com/CelebrityCruises \\
\hline Royal Caribbean Cruising & https://www.facebook.com/groups/royalcaribbeancruising \\
\hline MSC Cruises Fan Page & https://www.facebook.com/groups/271237986384019 \\
\hline Norwegian Cruise Line (NCL) Latitudes Members & https://www.facebook.com/groups/latitudeshq \\
\hline Holland America Line Fans & https://www.facebook.com/HALCruises \\
\hline Costa Cruise Lines Fans & https://www.facebook.com/groups/CostaCruisesFans \\
\hline P\&O Cruises-UK Fan Page & https://www.facebook.com/groups/pandocruises \\
\hline Cruise Foodies & https://boards.cruisecritic.com/forum/125-cruise-foodies/ \\
\hline
\end{tabular}

Potential female participants were introduced to the purpose of the study via a short explanatory section that was incorporated in the survey. Individuals that understood the purpose of the study and agreed to take part in the survey qualified to continue with the screening questions of the questionnaire. Screening questions were used to verify that only those female passengers who have cruised before and who had dined multiple times at dining rooms and themed/ethnic restaurants participated in the survey. Individuals were requested to answer on a nominal scale ("yes" or "no") to the following questions: "Have you cruised in the last 18 months?" and "Have you dined multiple times in one of the cruise ship's dining rooms, themed restaurants and ethnic restaurants?". A total of 390 questionnaires were collected and the average time taken by respondents to complete each questionnaire was $18 \mathrm{~min}$. Lastly, truthful revealing of information while completing the survey was achieved by means of confidentiality and anonymity of respondents.

The sample was composed of 390 female passengers from dominant cruise passenger markets ( $87.9 \%$ from North America and $12.1 \%$ from Europe). The majority of participants' ages fell within 41 to $60+$ years old, with $70 . \%$ being older than 61 years, $17.7 \%$ being in the age group between 51 and 60 years, $11.8 \%$ between 41 and 50 years and $0.5 \%$ being in the age group between 20 and 40 years. Regarding the education level, $51.8 \%$ indicated that they had a university degree, $33.6 \%$ specified that they had a college degree and $8.7 \%$ indicated that they had a Master's or PhD degree, while 5.9\% had a high school diploma. Lastly, the vast majority (98.7\%) had cruised more than 4 times, while $91 \%$ indicated that they cruised without children.

\subsection{Measures}

The survey contained a mix of multi-item and dual-item measures (see Appendix A Table A1 for a complete list of items). Scale items to assess the study variables were adopted from validated measurement items from the current literature and all but attitude (7-point Likert-type scale) were anchored on a 5-point Likert-type scale. Social servicescape had three items (e.g., "Interacting with other Guests is interesting" and "Attractive employees makes me feel good") and it was measured with the adjusted scale from Radić and Popesku [17]. Emotions with pleasure and arousal components were measured with two items from the adjusted Mehrabian and Russell [29] PAD scale. Attitude and subjective norms were adopted from Han et al.'s 2020 scale, where attitude was evaluated with three items (e.g., "Dining at this cruise dining place in the future is $(\ldots)$ ") and subjective norms were assessed with two items (e.g., "Most people who are important to me want me to 
dine at this cruise dining place in the future"). Perceived health risk from COVID-19 with three items (e.g., "The thought of dining at a cruise dining place makes me anxious although the COVID-19 pandemic is completely under control (or ceased) in the future") was measured with the adjusted scale from Al-Ansi et al. [72] (2019), while behavioral intentions with three items (e.g., "When other people ask you about your dining rooms experience on board cruise ship you will tell them positive things") were measured with the adjusted scale from Radić et al. [73]. The initial version of the questionnaire including these measurement items and questions about demographic profiles was thoroughly reviewed by academic experts and improved accordingly. To reduce the common method bias of self-administrated questionnaires [74], independent and dependent constructs were separately arranged so that they did not replicate the structure of the hypothesis [75].

\section{Results}

\subsection{Reliability and Validity Assessment}

A confirmatory factor analysis (CFA) and maximum likelihood estimation (MLE) approach was conducted to test whether or not the data fitted the measurement model. The result of the CFA shows that the model included a satisfactory level of the goodness-of-fit statistics $(\chi 2=157.485, \mathrm{df}=89, p<0.000, \chi 2 / \mathrm{df}=1.769, \mathrm{RMSEA}=0.044, \mathrm{CFI}=0.977$, $\mathrm{IFI}=0.977, \mathrm{TLI}=0.969)$. Standardized loadings between the observed variables and latent factors were all significant $(p<0.01)$. Complete details of the CFA results are exhibited in Table 2.

Table 2. Measurement model assessment.

\begin{tabular}{|c|c|c|c|c|c|c|c|c|}
\hline Constructs & 1 & 2 & 3 & 4 & 5 & 6 & AVE & CR \\
\hline 1. Perceived health risk & 1.000 & & & & & & 0.889 & 0.960 \\
\hline 2. Social servicescape & -0.041 & 1.000 & & & & & 0.439 & 0.700 \\
\hline 3. Behavioral intentions & -0.051 & 0.390 & 1.000 & & & & 0.584 & 0.805 \\
\hline 4. Attitude & 0.081 & 0.605 & 0.670 & 1.000 & & & 0.406 & 0.672 \\
\hline 5. Subjective norms & 0.016 & -0.293 & -0.258 & -0.365 & 1.000 & & 0.478 & 0.647 \\
\hline 6. Emotions & 0.172 & 0.433 & 464 & 0.749 & -0.418 & 1.000 & 0.676 & 0.807 \\
\hline
\end{tabular}

Goodness-of-fit statistics: $\chi 2=157.485, \mathrm{df}=89, p<0.000, \chi 2 / \mathrm{df}=1.769, \mathrm{RMSEA}=0.044, \mathrm{CFI}=0.977, \mathrm{IFI}=0.977, \mathrm{TLI}=0.969$.

Values of the composite reliability for research constructs fell between 0.647 and 0.960, which exceeded Bagozzi and Yi's [76] recommended cutoff of 0.600. This means that the measures for each construct are internally consistent. Convergent validity is generally supported as the values of the average variance extracted are close to or exceed the suggested level [76]. Thus, the convergent and discriminant validities of the measurement items were acceptable.

\subsection{Structural Model and Hypotheses Testing}

The proposed conceptual model based on the tripartite approach was estimated to examine the hypothesized relationships among the study variables and to evaluate the anticipation ability of the hypothesized conceptual framework. Hence, structural equation modeling (SEM) with an MLE approach was performed. The results of the SEM (please see Table 3) reveal that the model satisfactorily fitted the data $\left(\chi^{2}=243.834, \mathrm{df}=95, p<0.000\right.$, $\chi 2 / \mathrm{df}=2.567, \mathrm{RMSEA}=0.063, \mathrm{CFI}=0.949, \mathrm{IFI}=0.950, \mathrm{TLI}=0.936)$. The model contained an appropriate level of anticipation power for female passengers' behavioral intentions towards dining on cruise ships $\left(R^{2}=0.424\right)$. 
Table 3. Structural model assessment for female passengers $(n=390)$.

\begin{tabular}{|c|c|c|c|c|c|c|}
\hline \multicolumn{4}{|c|}{ Hypothesized Paths } & \multirow{2}{*}{$\begin{array}{c}\text { Coefficients } \\
0.812\end{array}$} & \multirow{2}{*}{$\frac{t \text {-Values }}{7.746^{* *}}$} & \multirow{2}{*}{$\frac{\text { Significant }}{\text { Yes }}$} \\
\hline H1 & Social servicescape & $\rightarrow$ & Attitude & & & \\
\hline $\mathrm{H} 2$ & Social servicescape & $\rightarrow$ & Emotions & 0.667 & $7.978 * *$ & Yes \\
\hline $\mathrm{H} 3$ & Emotions & $\rightarrow$ & Behavioral intentions & 0.115 & 1.612 & No \\
\hline $\mathrm{H} 4$ & Attitude & $\rightarrow$ & Behavioral intentions & 0.577 & $6.368^{* *}$ & Yes \\
\hline $\mathrm{H} 5$ & Subjective norms & $\rightarrow$ & Behavioral intentions & -0.004 & -0.055 & No \\
\hline H6 & Perceived health risk & $\rightarrow$ & Behavioral intentions & -0.099 & $-2.075 *$ & Yes \\
\hline \multicolumn{7}{|c|}{$\begin{array}{l}\text { Total variance explained: } \\
R^{2} \text { for Emotions }=0.444 \\
R^{2} \text { for Attitude }=0.659 \\
\text { for Behavioral intentions }=0.424\end{array}$} \\
\hline
\end{tabular}

Goodness-of-fit statistics: $\chi^{2}=243.834, \mathrm{df}=95, p<0.000, \chi^{2} / \mathrm{df}=2.567, \mathrm{RMSEA}=0.063, \mathrm{CFI}=0.949$. IFI $=0.950, \mathrm{TLI}=0.936,{ }^{*} p<0.05,{ }^{* *} p<0.01$.

In summary, the proposed conceptual model based on the tripartite approach was deemed adequate for the total variance in emotions (44.4\%), attitude $(65.9 \%)$ and behavioral intentions (42.4\%), which were all, as per Aneshensel [77], above the acceptable levels for studies in social sciences. Furthermore, the hypothesized relations between study variables were assessed. As laid out in Table 3 and Figure 2, social servicescape showed a significant and positive influence on female passengers' attitude $(\beta=0.812, p<0.01)$ and emotions ( $\beta=0.667, p<0.01)$. Hence, Hypotheses 1 and 2 are supported. Furthermore, while attitude significantly influences female passengers' behavioral intentions $(\beta=0.577$, $p<0.01)$, subjective norms $(\beta=-0.004, p<0.01)$ and emotions $(\beta=0.115, p<0.01)$ were not a significant predictor of female passengers' behavioral intentions. Consequently, Hypothesis 4 is supported, while Hypotheses 3 and 5 are not supported. Finally, perceived health risk from COVID-19 demonstrated a significant and negative effect on female passengers' behavioral intentions ( $\beta=-0.099, p<0.05)$; accordingly, Hypothesis 6 is supported.

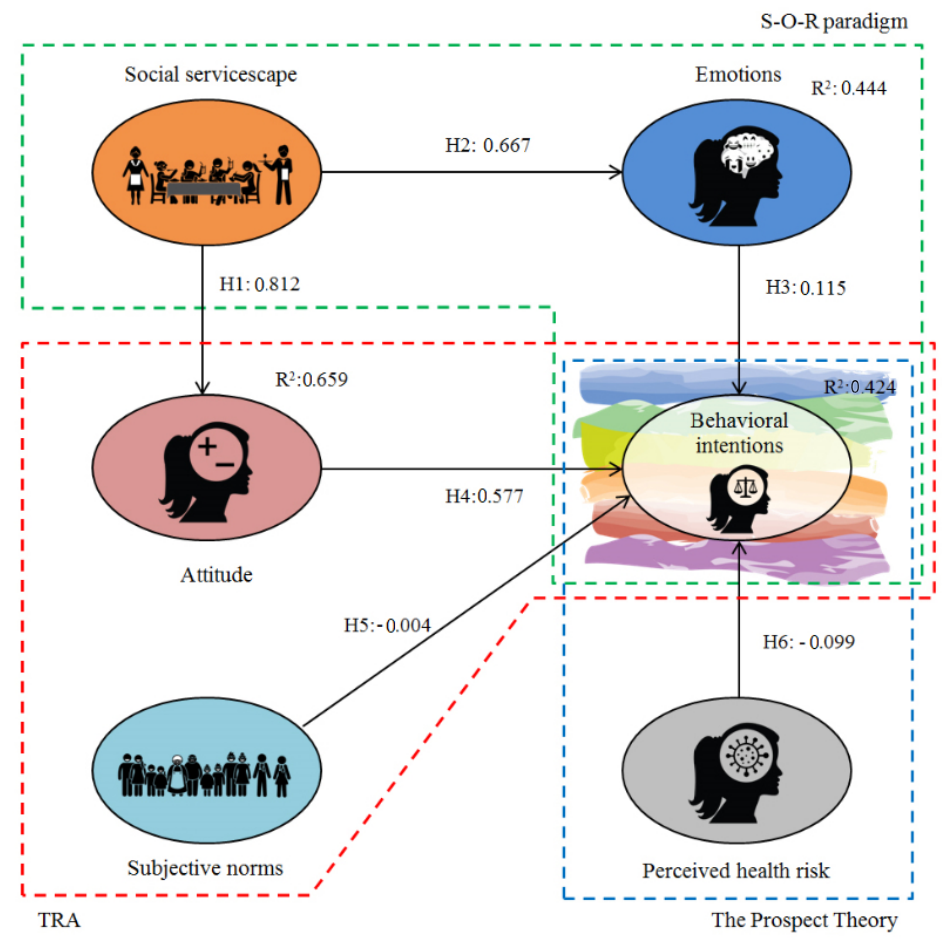

Figure 2. Results of the structural model estimation $(n=390)$. Note: goodness-of-fit statistics for the structural model: $\chi 2=243.834, \mathrm{df}=95, p<0.000, \chi 2 / \mathrm{df}=2.567$, RMSEA $=0.063, \mathrm{CFI}=0.949$, $\mathrm{IFI}=0.950, \mathrm{TLI}=0.936$. 


\section{Discussion}

The conceptual model based on the tripartite approach drawing on Mehrabian and Russell's [29] S-O-R paradigm, on Ajzen and Fishbein's [28] TRA and on Kahneman and Tversky's [30] prospect theory makes an important contribution towards understanding female passengers' behavioral intentions towards dining on cruise ships during the COVID19 incident. As seen in Figure 2, the reshaped model based on the tripartite approach demonstrated that despite the positive effect of the social servicescape on attitude and emotions, and despite the positive attitude of female passengers towards dining on a cruise ship, the negative effect of the perceived health risk from COVID-19 appears to be the dominant factor that ultimately discourages the behavioral intentions of female passengers towards dining on cruise ships in the time of the COVID-19 pandemic.

The social servicescape and dynamic interactions between service employees and guests and between guests themselves showed a positive effect on the female passengers' attitude and emotional responses. Social interactions in cruise ship dining rooms are motivated by empathy, the need for socialization and enjoyment of hedonic consumption. Furthermore, hedonic consumption during socialization boosts levels of endorphins, which are drivers of positive attitudes and positive emotions. What perhaps is most intriguing about this finding is the evident positive attitude of female passengers to board the secluded world of a cruise ship and enjoy dynamic social interactions during hedonic consumption while escaping from the daily pressure of the COVID-19 pandemic. This is most likely due to positive neurochemical feedback loops inside the human brain which reward social behavior. This finding was supported by Cruise Industry News [78] on 15 November 2020, which reported that more than 100,000 people have applied for free cruise trials as a part of the Royal Caribbean International cruise line company's effort to meet the CDC's Framework, despite surging numbers and new daily records of the COVID-19 reported cases across the USA.

Fear is one of the fundamental drivers when it comes to information processing at the subconscious level. Today, we are witnessing the wide spread of COVID-19 pandemicrelated information coming from various sources such as mainstream media, social media, government officials and health practitioners. In the case of the COVID-19 cruise tourism crisis, such sources are quite often using strong language and explicit aspects of narration to purposefully boost fear about the COVID-19 pandemic [8]. Moreover, vivid and disturbing images used in describing the severity of the COVID-19 pandemic and aggressive enforcement of strategies related to physical distancing, lockdowns and curfew, with government-issued warnings against traveling, have managed to spread fear. As nothing spreads like fear, it appears that female passengers' subjective norms may be affected by the sense of the fear and worries of their significant other and/or close social groups. Hence, as the human brain relies on heuristics to make certain judgments, subjective norms of female passengers are unsupportive towards the behavioral intention to dine on board cruise ships in the time of the coronavirus pandemic. Cruise tourism is all about positive emotions, but the COVID-19 pandemic has changed that and appears to have created a new emotional experience in the form of fear that prevents female passengers from experiencing positive emotions and exhibiting favorable behavioral intentions towards dining on board cruise ships in the time of the COVID-19 pandemic. This conclusion is supported by Brooks and Saad (2020), who argued that $60 \%$ of female U.S. residents are experiencing fear and worries about being infected by COVID-19, while Kiefer [79] outlined how fear, disgust and sometimes anger have become evident emotional responses related to protecting physical safety during the COVID-19 incident.

Female passengers' perceived health risk from COVID-19 pushes them into despair that over time evolves into fear. Once fear from the perceived health risk from COVID19 becomes the dominant emotion of female cruise travelers, they tend to avoid certain behaviors. This study shows that the perceived health risk from COVID-19 has a strong negative influence that discourages female passengers' behavioral intentions to dine on cruise ships in the time of the COVID-19 pandemic. This is most likely due to the influence 
of mass media that labeled cruise ships as crowded "petri dishes" [8] and the CDC's recently issued level 4 warning with the recommendation that all people should avoid traveling on cruise ships due to very high risk of COVID-19 on cruise ships [69].

\subsection{Theoretical Implications}

The novelty of the present study is that it is the first study to assess the behavioral intentions of female passengers towards dining on cruise ship in the era of the COVID-19 pandemic. In summary, three essential theoretical implications can be concluded from the findings of this research. First, our conceptual model succeeded in extending the TRA by introducing constructs that are analogous to the cruise ship dining experiencescape (S-O-R paradigm) and health risk perception due to COVID-19 (the prospect theory) into the theoretical foundation. More precisely, the constructs of the cruise ship dining experiencescape coupled with the perceived health risk from COVID-19 are accurately reflected in the process of behavioral intentions of female passengers towards dining on cruise ships in the time of the COVID-19 crisis. Furthermore, the scrutiny of the behavioral intentions of female passengers has mirrored the dominant role of the perceived health risk from COVID-19. The study results demonstrate that our proposed model based on the tripartite approach displayed robust explanatory power in understanding the behavioral intentions of female passengers towards dining on cruise ships in the time of the COVID-19 pandemic. Consequently, from a theoretical standpoint, this study successfully extended the original TRA in line with Ajzen's [80] benchmark for enhancing the theory.

From the general tourist behavior standpoint, this research has provided a fresh perspective in the context of what Perugini and Bagozzi [81] called strengthening and expanding the contemporary social theory in the tourist behavior literature. Specifically, the results from our study offer valuable insights into the behavioral intentions of female passengers by extending the existing TRA framework through the cruise ship dining experiencescape and perceived health risk from COVID-19. Encompassing three significant reciprocal constructs relating to the behavioral intentions of female passengers-social servicescape as the stimuli construct, emotional response as the organism construct and the perceived health risk from COVID 19 construct-our study reveals the antecedents of female passengers' behavioral intentions and exhibits a robust correlation among these constructs.

Second, the current study has unearthed the important role of attitude as a mediator in forming female passengers' behavior $(\beta=0.577, p<0.01)$. More precisely, the attitude of female passengers could be strengthened by the social servicescape of the cruise ship dining experiencescape (e.g., friendliness, helpfulness, empathy of service employees, socialization with other guests). Furthermore, the social servicescape demonstrated a positive influence on female passengers' emotional responses. These findings confirm the expanded nomological network of experiencescape conceptualized by Tasci and Pizam [82], Mehrabian and Russell's [29] S-O-R paradigm and Ajzen and Fishbein's [28] TRA in the particular conditions during the COVID-19 crisis. However, the results of this study reveal that subjective norms do not have a positive influence on female passengers' behavioral intentions towards dining on cruise ships in the COVID-19 pandemic era. Accordingly, in the case when subjective norms are heavily affected by the sense of the fear and worries of significant others and/or close social groups, subjective norms become unsupportive towards behavioral intentions. Lastly, the study also reveals that the emotional response of female passengers towards dining on cruise ships in the time of the COVID-19 pandemic is steered by feelings of fear which lead towards avoidance behavior. This finding also confirms Tasci and Pizam's [82] expanded nomological network of experiencescape and Mehrabian and Russell's [29] S-O-R paradigm.

Third, the results of this study discover that female passengers' perceived health risk from the COVID-19 pandemic has the characteristics described by Tversky and Kahneman, [43] p. 298, as "losses loom larger than gains". Hence, fear from being infected by COVID-19 in cruise ship dining rooms during paid cruise leisure proved to be perceived as a significant loss with a large impact on female passengers' health and physical safety, com- 
pared to the received gains from the empathy and need for socialization. These findings not only confirm Tversky and Kahneman's [43] prospect theory, but also findings from Yang et al. [83], who in their systematic literature review of risk and gender research in tourism outlined that females from Western cultures exhibit aversion towards health risks.

\subsection{Practical Implications}

While there is a glimpse of hope for the cruise industry as major cruise lines are rushing to find ways to restart their operations, there are still quite a few concerns related to how cruise line companies will mitigate female passengers' perceptions of the health risk from COVID-19; how cruise line companies will shift female cruise travelers' subjective norms from unfavorable to favorable; and how cruise line companies will encourage female passengers' approach behavior towards dining on cruise ships in the time of the COVID-19 pandemic. To accomplish such a daunting task, our study suggests that cruise line companies should pause and wait in restarting their operation as the overall climate related to the COVID-19 pandemic is still very much unfavorable as long as the pandemic is not under control and/or there is no vaccine widely available and public feelings are still dominated by fear.

Cruise line companies should carefully monitor the COVID-19 pandemic narration from mainstream media, social media, government officials and health practitioners. Once narration from these entities shifts from boosting fear to supporting hope, cruise line companies should engage in specifically tailored digital video marketing content that would target female passengers' personality traits. Such digital content should be based on feelings of hope as hope is a characteristic with a considerable effect on behavioral intentions. Once cruise line companies manage to mobilize feelings of hope in female passengers, our research and other studies suggest that female passengers will creatively deal with their fears and worries. Such marketing efforts should be expanded to the female passengers' significant others and/or social groups, through social media networks. This marketing effort would affect female passengers' subjective norms, emotional response and perceived health risk from COVID-19, ultimately leading to favorable behavioral intentions towards dining on cruise ships in the COVID-19 pandemic era.

Cruise line companies should not engage in berth rate discounts as a way to ease substantial revenue loss and stimulate financial recovery. To mitigate the perceived health risks from COVID-19, it is suggested that cruise line companies should instead offer shortterm promotional packages aimed at attracting female passengers. These might include free cancelations up to one year, flexible departure cruise dates up to one year, free-of-charge cruises for children under 17 years old, discounts for housewives, discounts for single moms sailing with children, discounts for lesbian couples with/without children, discounts for female victims of domestic violence, discounts for females 60+ years old, onboard credit for drinks in restaurants, free Wi-Fi with \#Ilove(name of cruise line company) and a posted photo on Instagram or Facebook, daily gratuities included, discounts for activities and excursions to private islands and ports of call, free transfers to and from the homeport and gift cards on purchased treatments in cruise ship spas.

Once CDC conditions allow cruises to resume, cruise line companies should implement tactics that would provide an overall strategic framework to mitigate the risks from the COVID-19 infection. Such tactics could include the following:

(1) Terminate refers to all known methods to eliminate any opportunity of spreading of COVID-19 (e.g., health screening of guests and crew prior to boarding and during the cruise, negative PCR test prior to boarding and during the cruise if needed and sailing with reduced capacities).

(2) Bifurcate refers to maintaining physical distancing while being on board (e.g., enforcing the physical distancing of $2 \mathrm{~m}$ between guests and between guests and the crew).

(3) Isolate refers to wearing face coverings while being on board except when eating or drinking (e.g., in dining rooms, servers should wear face coverings together with a 
face shield, or at purser desks, physical barriers between guests and the crew should be installed (for close interaction with less than $1 \mathrm{~m}$ distance)).

(4) Disable refers to hygiene practices (hand washing and hand sanitizers) and increased cleaning and sanitizing frequencies of hard surfaces.

Furthermore, the dynamic interaction between service employees and guests has to be sincere, open, friendly and, above all, pleasant. Similarly, interactions between guests themselves have to be managed in a way that all involved participants feel pleasure from being able to fulfill their need for socialization. Female passengers are passionate members of this floating micro-community, and therefore cruise line companies have to carefully manage the social servicescape of the cruise ship dining experiencescape.

\subsection{Limitations and Future Research}

This pioneering study is not without limitations that can offer opportunities for future studies. The first limitation is the use of an online self-administered survey, which means that caution should be applied in generalizing the findings due to self-response bias. However, to lessen this challenge, the survey in this study was composed and validated, following the recommendation of Podsakoff et al. [74], in such a manner that independent and dependent variables did not replicate the structure of the hypotheses. The second limitation is that the participants are from societies with the Western cultural perspective. Consequently, the results could differ with participants from societies with other cultural perspectives. Accordingly, future research should involve female passengers that are from societies that are not rooted in the Western cultural perspective. Despite these limitations, to the authors' best knowledge, the present research is the first to investigate the behavioral intentions of female cruise travelers towards dining on cruise ships in the time of the COVID-19 pandemic.

Author Contributions: Conceptualization, A.R. (Aleksandar Radic), H.H. and A.A.-A.; methodology, A.R. (Aleksandar Radic), H.H. and M.L.; formal analysis, A.R. (Aleksandar Radic), H.H. and A.A.-A.; investigation, A.R. (Aleksandar Radic); resources, H.H. and M.L.; writing—original draft preparation, A.R. (Aleksandar Radic), H.H., B.-L.C., S.S. and M.L.; writing-review and editing, A.R. (Aleksandar Radic), H.H., B.-L.C., S.S. and M.L.; visualization, A.R. (Aleksandar Radic), A.R. (António Raposo) and J.J.K.; supervision, H.H. and M.L.; funding acquisition, H.H., A.R. (António Raposo). and J.J.K. All authors have read and agreed to the published version of the manuscript.

Funding: This research received no external funding.

Institutional Review Board Statement: Because of the observational nature of the study, and in the absence of any involvement of therapeutic medication, no formal approval of the institutional review board of the local ethics committee was required. Nonetheless, all subjects were informed about the study and participation was fully on a voluntary basis. The study was conducted in accordance with the Helsinki Declaration.

Informed Consent Statement: Not applicable.

Acknowledgments: The authors would like to thank Elizabeth Turner (Auckland University of Technology) for the meticulous review of the manuscript.

Conflicts of Interest: The authors declare no conflict of interest. 


\section{Appendix A}

Table A1. Constructs and measurement items.

\begin{tabular}{|c|c|c|c|}
\hline Constructs and Items & Loadings & Mean & SD \\
\hline \multicolumn{4}{|l|}{$\begin{array}{l}\text { Social servicescape } \\
\text { Strongly Disagree (1)_Strongly Agree (5) }\end{array}$} \\
\hline - Interacting with other Guests is interesting. & 0.688 & 4.11 & 0.616 \\
\hline - $\quad$ Socializing with other Guests is exciting. & 0.717 & 4.09 & 0.642 \\
\hline - $\quad$ Attractive employees makes me feel good. & 0.575 & 4.14 & 0.572 \\
\hline \multicolumn{4}{|l|}{ Emotions } \\
\hline - $\quad$ Annoyed (1) Pleased (5). & 0.804 & 4.39 & 0.539 \\
\hline • $\quad$ Unhappy (1) Happy (5). & 0.840 & 4.49 & 0.521 \\
\hline \multicolumn{4}{|l|}{$\begin{array}{l}\text { Attitude } \\
\text { Dining at this cruise dining place in the future is }\end{array}$} \\
\hline - $\quad \operatorname{Bad}(1) \sim \operatorname{Good}(7)$ & 0.640 & 6.03 & 0.656 \\
\hline - $\quad$ Foolish (1) Wise (7). & 0.618 & 6.53 & 0.628 \\
\hline - $\quad$ Unpleasant (1) Pleasant (7). & 0.654 & 6.12 & 0.454 \\
\hline
\end{tabular}

Subjective norms

Strongly Disagree (1)—Strongly Agree (5)

- Most people who are important to me want me to dine at this cruise dining place in the future.

0.660

0.722

- $\quad$ People whose opinions I value prefer that I dine at this cruise dining place in the future.

\section{Perceived health risk}

Strongly Disagree (1)—Strongly Agree (5)

- The thought of dining at a cruise dining place makes me anxious although the COVID-19 pandemic is completely under control (or ceased) in the future.

- The thought of dining at a cruise dining place makes me feel psychologically uncomfortable although the COVID-19 pandemic is completely under control (or ceased) in the future.

- The thought of dining at a cruise dining place causes me to experience unnecessary tension although the COVID-19 pandemic is completely under control (or ceased) in the future.
0.992

\section{Behavioral intentions}

Strongly Disagree (1)—Strongly Agree (5)

- When other people ask you about your dining rooms experience on board cruise ship you will tell them positive things.

- If someone asks your advice about cruise ship dining you will recommend dining rooms.

- You will encourage your friends and family to dine on cruise ships.

\section{References}

1. Radic, A. Towards an understanding of a child's cruise experience. Curr. Issues Tour. 2019, 22, 237-252. [CrossRef]

2. Cruise Lines International Association. 2020 State of the Cruise Industry Outlook. Available online: https://cruising.org/en/ news-and-research/press-room/2019/december/clia-releases-2020-state-of-the-cruise-industry-outlook-report (accessed on 22 January 2021).

3. Statista Research Department. Expected Passenger Cruise Capacity in Operation Worldwide from May 2020 to January 2021, by Month. Available online: https://www.statista.com/statistics/1119828/cruise-capacity-in-operation-forecast-monthly / (accessed on 22 December 2020).

4. Cruise Market Watch. Growth of the Ocean Cruise Line Industry. Available online: https://cruisemarketwatch.com/growth/ (accessed on 22 January 2021). 
5. Cruise Industry News. Cruise Ships Back in Service January 2021 Update. Available online: https: / www.cruiseindustrynews. com/cruise-news/24135-cruise-ships-back-in-service-january-2021-update.html (accessed on 22 January 2021).

6. Lück, M.; Seeler, M.; Radic, A. Hitting the reset button for post-COVID-19 cruise tourism: The case of Akaroa, New Zealand. Acad. Lett. 2021, in press.

7. Cruise Industry News. Here's How Much Cash the Cruise Lines Are Burning Through. Available online: https://www. cruiseindustrynews.com/cruise-news/23908-here-are-the-cruise-lines-operating-right-now.html (accessed on 22 January 2021).

8. Radic, A.; Law, R.; Lück, M.; Kang, H.; Ariza-Montes, A.; Arjona-Fuentes, J.-M.; Han, H. Apocalypse Now or Overreaction to Coronavirus: The Global Cruise Tourism Industry Crisis. Sustainability 2020, 12, 6968. [CrossRef]

9. Sharma, A.; Nicolau, J.L. An open market valuation of the effects of COVID-19 on the travel and tourism industry. Ann. Tour. Res. 2020, 83, 102990. [CrossRef] [PubMed]

10. Erdmann, F. Amid Order Shifts, Cutbacks, Cruise Market will Need a Decade to Recover: Bernard Meyer. Available online: https:// www.seatrade-cruise.com/news/amid-order-shifts-cutbacks-cruise-market-will-need-decade-recover-bernard-meyer (accessed on 22 January 2021).

11. Centers for Disease Control and Prevention. Framework for Conditional Sailing and Initial Phase COVID-19 Testing Requirements for Protection of Crew. Available online: https:/ / www.cdc.gov/quarantine/pdf/CDC-Conditional-Sail-Order_10_30_2020-p.pdf (accessed on 22 January 2021).

12. Centers for Disease Control and Prevention. Second Modification and Extension of No Sail Order and Other Measures Related to Operations. Available online: https://www.cdc.gov/quarantine/pdf/No-Sail-Order-Cruise-Ships-Second-Extension_07_16_ 2020-p.pdf (accessed on 22 January 2021).

13. Bennett, M. Competing with the Sea: Contemporary cruise ships as omnitopias. PAJ 2016, 21, 50-57. [CrossRef]

14. Lallani, S.S. Mediating cultural encounters at sea: Dining in the modern cruise industry. J. Tour. Hist. 2017, 9, 160-177. [CrossRef]

15. Lallani, S.S. The world on a ship: Producing cosmopolitan dining on mass-market cruises. Food Cult. Soc. 2019, 22, 485-504. [CrossRef]

16. Lyu, J.; Hu, L.; Hung, K.; Mao, Z. Assessing servicescape of cruise tourism: The perception of Chinese tourists. Int. J. Contemp. Hosp. Manag. 2017, 29, 2556-2572. [CrossRef]

17. Radić, A.; Popesku, J. Quality of cruise experience: Antecedents and consequences. Teme 2018, 42, 523-539.

18. Liu, T.; Li, M.; Wu, M. Performing femininity: Women at the top (doing and undoing gender). Tour. Manag. 2020, 80, 103130. [CrossRef]

19. Durko, A.M.; Stone, M.J. Even lovers need a holiday: Women's reflections of travel without their partners. Tour. Manag. Perspect. 2020, 21, 18-23. [CrossRef]

20. Chrusciel, B. Best Cruises for Single Women. Available online: https:/ /www.cruisecritic.com/articles.cfm?ID=3457 (accessed on 22 January 2021).

21. Cruise Lines International Association. 2019 Cruise, Trends \& Industry Outlook. Available online: https:// cruising.org/-/media/ eu-resources/pdfs/CLIA\%202019-Cruise-Trends--Industry-Outlook (accessed on 22 January 2021).

22. Figueroa-Domecq, C.; Pritchard, A.; Segovia-Perez, M.; Morgan, N.; Villace-Moliero, T. Tourism gender research: A critical accounting. Ann. Tour. Res. 2015, 52, 87-103. [CrossRef]

23. Brown, L.; Osman, H. The female tourist experience in Egypt as Islamic destination. Ann. Tour. Res. 2017, 63, 12-22. [CrossRef]

24. Ajzen, I. Consumer attitudes and behavior: The theory of planned behavior applied to food consumption decisions. Ital. Rev. Agric. Econ. 2016, 70, 121-138.

25. Karl, M.; Muskat, B.; Ritchie, B. Which travel risks are more salient for destination choice? An examination of the tourist's decision-making process. J. Destin. Mark. Manag. 2020, 18, 10487. [CrossRef]

26. Cruise Industry News. Norwegian to Have Trial Cruises as Early as January. Available online: https:/ / www.cruiseindustrynews. com/cruise-news/23844-norwegian-to-have-trial-cruises-as-early-as-january.html (accessed on 22 January 2021).

27. Brooks, D.J.; Saad, L. The COVID-19 Responses of Men vs. Women. Available online: https://news.gallup.com/opinion/gallup/ 321698/covid-responses-men-women.aspx (accessed on 22 January 2021).

28. Ajzen, I.; Fishbein, M. Understanding Attitudes and Predicting Social Behavior; Prentice-Hall Inc.: Englewood Cliffs, NJ, USA, 1980.

29. Mehrabian, A.; Russell, J.A. An Approach to Environmental Psychology; Massachusetts Institute of Technology: Cambridge, MA, USA, 1974.

30. Kahneman, D.; Tversky, A. Prospect theory: An analysis of decision under risk. Econometrica 1979, 47, 263-291. [CrossRef]

31. Pizam, A.; Tasci, A.D. Experienscape: Expanding the concept of servicescape with a multi-stakeholder and multi-disciplinary approach (invited paper for 'luminaries' special issue of International Journal of Hospitality Management). Int. J. Hosp. Manag. 2019, 76, 25-37. [CrossRef]

32. Wang, L.; Didelot, X.; Yang, J.; Wong, G.; Shi, Y.; Liu, W.; Gao, F.; Bi, Y. Inference of person-to-person transmission of COVID-19 reveals hidden super-spreading events during the early outbreak phase. Nat. Commun. 2020, 11, 5006. [CrossRef]

33. Hanks, L.; Line, N.D. The restaurant social servicescape: Establishing a nomological framework. Int. J. Hosp. Manag. 2018, 74, 13-21. [CrossRef]

34. Calza, F.; Pagliuca, M.; Risitano, M.; Sorrentino, A. Testing moderating effects on the relationships among on-board cruise environment, satisfaction, perceived value and behavioral intentions. Int. J. Contemp. Hosp. Manag. 2020, 32, 934-962. [CrossRef] 
35. Leong, M.W.; Yeh, S.-S.; Fan, Y.-L.; Huan, T.-C. The effect of cuisine creativity on customer emotions. Int. J. Hosp. Manag. 2020, 85, 102346. [CrossRef]

36. Ajzen, I. Martin Fishbein's Legacy: The Reasoned Action Approach. Ann. Am. Acad. Pol. Soc. Sci. 2012, 640, 11-27. [CrossRef]

37. Ajzen, I.; Fishbein, M. Attitude-behavior relations: A theoretical analysis and review of empirical research. Psychol. Bull. 1977, 84, 888-918. [CrossRef]

38. Amaro, S.; Andreu, L.; Huang, S. Millenials' intentions to book on Airbnb. Curr. Issues Tour. 2018, 22, 2284-2298. [CrossRef]

39. Ribeiro, M.A.; Pinto, P.; Silva, J.A.; Woosnam, K.Y. Residents' attitudes and the adoption of pro-tourism behaviours: The case of developing island countries. Tour. Manag. 2017, 61, 523-537. [CrossRef]

40. Sukhu, A.; Choi, H.; Bujisic, M.; Bilgihan, A. Satisfaction and positive emotions: A comparison of the influence of hotel guests' beliefs and attitudes on their satisfaction and emotions. Int. J. Contemp. Hosp. Manag. 2019, 77, 51-63. [CrossRef]

41. Bronner, F.; de Hoog, R. The floating vacationer: Destination choices and the gap between plans and behavior. J. Destin. Mark. Manag. 2020, 16, 100438. [CrossRef]

42. Rossiter, J.R. A critique of prospect theory and framing with particular reference to consumer decisions. J. Consum. Behav. 2019, 18, 399-405. [CrossRef]

43. Tversky, A.; Kahneman, D. Advances in prospect theory: Cumulative representation of uncertainty. J. Risk Uncertain. 1992, 5, $297-323$. [CrossRef]

44. Desmoulins-Lebeault, F.; Meunier, L.; Ohadi, S. Does Implied Volatility Pricing Follow the Tenets of Prospect Theory? J. Behav. Financ. 2020, 21, 157-173. [CrossRef]

45. Chiu, C.M.; Wang, E.T.; Fang, Y.H.; Huang, H.Y. Understanding customers' repeat purchase intentions in B2C e-commerce: The roles of utilitarian value, hedonic value and perceived risk. Inf. Syst. J. 2014, 24, 85-114. [CrossRef]

46. Olya, H.G.T.; Al-Ansi, A. Risk assessment of halal products and services: Implication for tourism industry. Tour. Manag. 2018, 65, 103130. [CrossRef]

47. Chen, J.M.; de Groote, J.; Petrick, J.F.; Lu, T.; Nijkamp, P. Travellers' willingness to pay and perceived value of time in ride-sharing: An experiment on China. Curr. Issues Tour. 2020, 23, 2972-2985. [CrossRef]

48. Zolfagharian, M.; Rajamma, R.K.; Naderi, I.; Torkzadeh, S. Determinants of medical tourism destination selection process. J. Hosp. Mark. Manag. 2018, 27, 775-794. [CrossRef]

49. Hanks, L.; Line, N.; Kim, W.G. The impact of the social servicescape, density, and restaurant type on perceptions of interpersonal service quality. Int. J. Hosp. Manag. 2017, 61, 35-44. [CrossRef]

50. Meng, B.; Choi, K. An investigation on customer revisit intention to theme restaurants: The role of servicescape and authentic perception. Int. J. Contemp. Hosp. Manag. 2018, 30, 1464-1662. [CrossRef]

51. Meng, B.; Cui, M. The role of co-creation experience in forming tourists' revisit intention to home-based accommodation: Extending the theory of planned behavior. Tour. Manag. Perspect. 2020, 33, 100581. [CrossRef]

52. Torres, E.N.; Wei, W.; Hua, N.; Chen, P.-J. Customer emotions minute by minute: How guests experience different emotions within the same service environment. Int. J. Hosp. Manag. 2019, 77, 128-138. [CrossRef]

53. Kim, E.; Tang, L.; Bosselman, R. Measuring customer perceptions of restaurant innovativeness: Developing and validating a scale. Int. J. Hosp. Manag. 2018, 74, 85-98. [CrossRef]

54. Chan, W.L.; Ho, J.A.; Sambasivan, M.; Ng, S.I. Antecedents and outcome of job embeddedness: Evidence from four and five-star hotels. Int. J. Hosp. Manag. 2019, 83, 37-45. [CrossRef]

55. Sthapit, E.; Björk, P.; Coudounaris, D.N. Emotions elicited by local food consumption, memories, place attachment and behavioural intentions. Anatolia 2017, 28, 363-380. [CrossRef]

56. Sok, J.; Borges, J.R.; Schmidt, P.; Ajzen, I. Farmer Behaviour as Reasoned Action: A Critical Review of Research with the Theory of Planned Behaviour. J. Agric. Econ. 2020, 1-25. [CrossRef]

57. Zenker, S.; Kock, F. The coronavirus pandemic-A critical discussion of a tourism research agenda. Tour. Manag. 2020, 81, 104164. [CrossRef]

58. Moon, S.-J. Investigating beliefs, attitudes, and intentions regarding green restaurant patronage: An application of the extended theory of planned behavior with moderating effects of gender and age. Int. J. Hosp. Manag. 2021, 92, 102727. [CrossRef]

59. Shin, Y.H.; Im, J.; Jung, S.E.; Severt, K. The theory of planned behavior and the norm activation model approach to consumer behavior regarding organic menus. Int. J. Hosp. Manag. 2018, 69, 21-29. [CrossRef]

60. Salehi-Esfahani, S.; Kang, J. Why do you use Yelp? Analysis of factors influencing customers' website adoption and dining behavior. Int. J. Hosp. Manag. 2019, 78, 179-188. [CrossRef]

61. Lin, N.; Roberts, K.R. Using the theory of planned behavior to predict food safety behavioral intention: A systematic review and meta-analysis. Int. J. Hosp. Manag. 2020, 90, 102612. [CrossRef]

62. Han, H.; Al-Ansi, A.; Chua, B.-L.; Tariq, B.; Radic, A.; Park, S.-H. The Post-Coronavirus World in the International Tourism Industry: Application of the Theory of Planned Behavior to Safer Destination Choices in the Case of US Outbound Tourism. Int. J. Environ. Res. Public Health 2020, 17, 6485. [CrossRef]

63. Sánchez-Cañizares, S.; Cabeza-Ramírez, L.J.; Muñoz-Fernández, G.; Fuentes-García, F.J. Impact of the perceived risk from Covid-19 on intention to travel. Curr. Issues Tour. 2020, 1-15. [CrossRef]

64. Shin, H.; Kang, J. Reducing perceived health risk to attract hotel customers in the COVID-19 pandemic era: Focused on technology innovation for social distancing and cleanliness. Int. J. Hosp. Manag. 2020, 91, 102664. [CrossRef] [PubMed] 
65. Baker, D.; Stockton, S. Smooth sailing! Cruise passengers' demographics and health perceptions while cruising the Eastern Caribbean. Int. J. Bus. 2013, 4, 8-17.

66. Holland, J. Risk perceptions of health and safety in cruising. AIMS Geosci. 2020, 6, 422-436. [CrossRef]

67. Walker, J. The Latest on the SeaDream 1 COVID-19 Debacle-What Went Wrong. Available online: https:/ / www.cruiselawnews. com/2020/11/articles/disease/the-latest-on-the-seadream-1-covid-19-debacle-what-went-wrong/ (accessed on 22 January 2021).

68. Bryant, S. Just Back from SeaDream: Lessons the Cruise Industry Can Learn from A COVID-Interrupted Trip. Available online: https: / / www.cruisecritic.com/articles.cfm?ID=5744 (accessed on 22 January 2021).

69. Centers for Disease Control and Prevention. COVID-19 and Cruise Ship Travel. Available online: https://wwwnc.cdc.gov / travel/notices/covid-4/coronavirus-cruise-ship (accessed on 22 January 2021).

70. Dataessential Report. COVID-19 Report 40: Winter is Coming. Available online: https://datassential.com/wp-content/uploads/ 2020/11/Datassential-Coronavirus40-11-13-20.pdf (accessed on 22 December 2020).

71. Teeroovengadum, V.; Nunkoo, R. Sampling design in tourism and hospitality research. In Handbook of Research Methods for Tourism and Hospitality Management; Nunkoo, R., Ed.; Edward Elgar Publishing: Cheltenham, UK, 2018; pp. 477-488.

72. Al-Ansi, A.; Olya, H.G.T.; Han, H. Effect of general risk on trust, satisfaction, and recommendation intention for halal food. Int. J. Hosp. Manag. 2019, 83, 210-219. [CrossRef]

73. Radić, A.; Björk, P.; Kauppinen-Räisänen, H. Cruise Holidays: How On-Board Service Quality Affects Passengers' Behavior. Tour. Mar. Environ. 2019, 14, 45-59. [CrossRef]

74. Podsakoff, P.M.; MacKenzie, S.B.; Lee, J.; Podsakoff, N.P. Common method biases in behavioral research: A critical review of the literature and the recommended remedies. J. Appl. Psychol. 2003, 88, 879-903. [CrossRef] [PubMed]

75. Terglav, K.; Ruzzier, M.K.; Kaše, R. Internal branding process: Exploring the role of mediators in top management's leadershipcommitment relationship. Int. J. Hosp. Manag. 2016, 54, 1-11. [CrossRef]

76. Bagozzi, R.P.; Yi, Y. On the evaluation of structural equation models. J. Acad. Mark. Sci. 1988, 16, 74-94. [CrossRef]

77. Aneshensel, C.S. Theory-Based Data Analysis for the Social Science, 2nd ed.; Sage Publications: Thousand Oaks, CA, USA, 2013.

78. Cruise Industry News. Royal Caribbean Sees 100,000 Sign Ups for Free Volunteer Cruises. Available online: https://www. cruiseindustrynews.com/cruise-news/23878-royal-caribbean-sees-100-000-sign-ups-for-free-volunteer-cruises.html (accessed on 22 January 2021).

79. Kiefer, P. Will We Ever Trust Crowds Again? Available online: https://www.nationalgeographic.com/science/2020/09/coronaviruswill-we-ever-trust-crowds-again-cvd (accessed on 22 January 2021).

80. Ajzen, I. The theory of planned behavior. Organ. Behav. Hum. Decis. Process. 1991, 50, 179-211. [CrossRef]

81. Perugini, M.; Bagozzi, R.P. The role of desires and anticipated emotions in goal-directed behaviors: Broadening and deepening the theory of planned behavior. Br. J. Soc. Psychol. 2001, 40, 70-98. [CrossRef] [PubMed]

82. Tasci, A.D.; Pizam, A. An expanded nomological network of experienscape. Int. J. Hosp. Manag. 2019, 32, 999-1040. [CrossRef]

83. Yang, E.C.L.; Khoo-Lattimore, K.; Arcodia, C. A systematic literature review of risk and gender research in tourism. Tour. Manag. 2017, 58, 89-100. [CrossRef] 